\title{
Immunoassay Test for Evaluation of Seroprevalence of HBV and HCV Infection among Patients Attending a Tertiary Care Hospital
}

\author{
P. Prabina ${ }^{1}$, S. Jayanthi ${ }^{*}$, A.S. Shameem Banu ${ }^{1}$ and S.R. Sakunthala ${ }^{2}$ \\ ${ }^{1}$ Department of Microbiology, ${ }^{2}$ Department of General Medicine, CARE-Chettinad Academy \\ of Research and Education, India \\ *Corresponding author
}

\section{A B S T R A C T}

\begin{tabular}{|c|c|}
\hline & nportant cause of \\
\hline Keywords & $\begin{array}{l}\text { morbidity and mortality. Aim of the study is to assess the seroprevalence of Hepatitis B } \\
\text { and Hepatitis } \mathrm{C} \text { viral infection among patients attending a tertiary care hospital. A }\end{array}$ \\
\hline $\begin{array}{l}\text { Hepatitis B Surface } \\
\text { Antigen (HBsAg), Anti } \\
\text { HCV Ab, Seroprevalence, } \\
\text { Immunoassay test }\end{array}$ & $\begin{array}{l}\text { prospective study was done from a period of } 20 \text { months (May } 2016 \text { to December 2017) on } \\
\text { patients attending a tertiary care hospital. Serum samples were taken from patients for } \\
\text { testing HBV and HCV infection using rapid immunochromatographic test and ELISA. A }\end{array}$ \\
\hline Article Info & $\begin{array}{l}\text { total number of } 39874 \text { patients were screened for HBsAg and anti HCV Ab. Among them; } \\
249 \text { were HBsAg positive }(0.62 \%), 51 \text { were anti HCV Ab positive }(0.1 \%) \text {. Majority of the }\end{array}$ \\
\hline $\begin{array}{l}\text { Accepted: } \\
\text { 04 February } 2018 \\
\text { Available Online: } \\
10 \text { March } 2018\end{array}$ & $\begin{array}{l}\text { HBsAg positive patients belonged to age group } 38-47 \text { years }(28.1 \%) \text { and anti HCV Ab } \\
\text { positive patients belonged to age group 58- } 67 \text { years }(47.0 \%) \text {. Only one patient was found } \\
\text { with a co-infection with both HBsAg and HCV positive. The screening of Hepatitis B and } \\
\text { Hepatitis C viral infection among the patients attending a tertiary care hospital enlightens } \\
\text { the details of seropositive being unnoticed. }\end{array}$ \\
\hline
\end{tabular}

\section{Introduction}

Viral Hepatitis is a major healthcare problem. Hepatitis B and Hepatitis C virus are the two most common hepatotrophic viruses responsible for majority of acute and chronic hepatitis (Wang S et al., 2017). Hepatitis B infection is the 10th leading cause of death and annually one million die from HBV associated liver disease (Teresa L et al., 2006). Worldwide prevalence of HBsAg varies between 0.1 to $11.7 \%$ (Koshy J et al., 2014). In India prevalence in general population 2$8 \%$ and among the blood donors 1- 2\% (Gupta et al., 2004, Datta et al., 2008, Panda et al., 2008). Every year 100,000 Indians die due to HBV infection related illness (WHO, 2015). Hepatitis C virus affects more than 170 million people around the world (Moosavy et al., 2017). WHO report of Hepatitis C suggests its prevalence $3 \%$ in the world which is a significant burden on public health (WHO, 2012). In India, seroprevalence of HCV infection is $1.8 \%$ among the general population (Chakravarti et al., 2013).

Hepatitis B and Hepatitis C virus are the main causes of severe liver disease, including 
chronic hepatitis, hepatocellular carcinoma and cirrhosis- related end- stage liver disease (Kanodia et al., 2015). They share a common risk factors and mode of transmission includes exposure to infected blood, various body fluids such as saliva, menstrual, vaginal and seminal fluids. Unvaccinated heterosexual and homosexual men are highly prone to hepatitis B infection (WHO, 2017).

Among all body fluids serum sample shows high HBV titre values. The Hepatitis B surface antigen (HBsAg) in serum is the first seromarker to indicate HBV infection, either acute or chronic (Horvat et al., 2011). The presence of anti-hepatitis $\mathrm{C}$ virus antibody (anti $\mathrm{HCV} \mathrm{Ab}$ ) indicates exposure to hepatitis $\mathrm{C}$ virus. This antibody is found to be association with $95 \%$ of chronic infections (Baheti et al., 2000).

The present study was designed to assess the seroprevalence of Hepatitis B and Hepatitis C viral infection among patients attending a tertiary care hospital using rapid immunochromatographic test and ELISA.

\section{Materials and Methods}

Hepatitis B and Hepatitis C virus are among the principal causes of severe liver disease. A prospective study was done from a period of 1 year 8 months (May 2016 to December 2017) on patients attending a tertiary care hospital. A total of 39874 patients were included in the study and their samples were taken for testing HBsAg and anti HCV Ab. Samples from the age groups below 18 years and above 67 years were excluded from the study. Samples were collected under aseptic condition and were subjected for anti $\mathrm{HCV} \mathrm{Ab}$ and $\mathrm{HBsAg}$ screening by rapid card method and confirmation was done by ELISA. Using the commercially available rapid test kit (Orchid Biomedical Systems, A Division of Tulip Diagnostics (P) Ltd., Goa, India). Venous blood sample $(3 \mathrm{ml})$ was drawn from each patient in a labelled plain vacutainer tube. Blood was allowed to clot and sera was separated and stored at $-20^{\circ} \mathrm{C}$ until tested for $\mathrm{HBsAg}$ and anti HCV Ab. The procedures were executed as per the kit as follows: The samples were brought to room temperature before performing the analysis. $50 \mu 1$ of the serum was dispensed in to the sample well of the card. The results were interpreted in 15 minutes. The results are as follows: the presence of two colour bands on " $\mathrm{T}$ " test line and " $\mathrm{C}$ " control line indicates a positive result. The presence of only one band on "C" (Control) line indicates a negative result. The test should be considered invalid if no coloured band appears on the device. The test should also be considered invalid if a coloured band appears only at the test region ' $\mathrm{T}$ ' and not at the control region ' $\mathrm{C}$ '. In such cases, repeat the test with a new device, ensuring that the test procedure has been followed accurately.

All the samples were tested for HBsAg using the enzyme linked immunosorbent assay (Transasia Bio- Medicals LTD, India). The procedures were executed as per the kit as follows: Bring all reagents and test specimens at room temperature before use. Add $50 \mu 1$ of sample diluent to each well. In each run, there will be one blank $(100 \mu 1$ sample diluent plus $50 \mu 1$ conjugate), three negative controls and one positive control. Add $50 \mu \mathrm{l}$ of control and test specimens to the respective wells. Add $50 \mu 1$ of conjugate to each well. Cover the plate with black cover and incubate 60 minutes at $20-37^{\circ} \mathrm{C}$. Wash the plate as per microplate washing procedure. Add 50 $\mu 1$ of colour reagent. Cover the plate with black cover and incubate for 15 minutes in dark at $20-30^{\circ} \mathrm{C}$. Add $100 \mu$ l of stopping buffer to each well. Read absorbancy at $450 \mathrm{~nm}$ (using 630nm as reference wavelength). Deduct blank absorbancy from the control and the test wells. The interpretations of the result are as follows: If the absorbancy of the test serum is less than 
0.1 , then the sample is considered as negative. If the absorbancy of the test serum is equal or greater than 1, then the sample is considered as positive.

All the samples were tested for anti $\mathrm{HCV} \mathrm{Ab}$ using third generation ELISA method (Qualpro diagnostics. A Division of Tulip Diagnostics (P) Ltd, Goa, India). The procedures were executed as per the kit as follows: Bring all reagents and test specimens at room temperature before use. Add $200 \mu 1$ of sample diluent to separate wells. Add $10 \mu \mathrm{l}$ of control specimen in the wells. Then gently shake the plate to mix thoroughly and apply plate sealer and incubate for 30 minutes at 22$28^{\circ} \mathrm{C}$. Wash each well by filling approximately $350 \mu \mathrm{l}$ diluted wash buffer and aspirating off six times. Then blot dry and add $100 \mu 1$ substrate and incubate at $22-28^{\circ} \mathrm{C}$ away from light for 30 minutes and stop reaction by adding $100 \mu \mathrm{l}$ stop solution. Then read the absorbance at $450 \mathrm{~nm}$ with $600-700 \mathrm{~nm}$ as reference within 30 minutes of stopping the reaction. Samples with absorbance value less than 0.1 are considered non-reactive. Samples with absorbance value equal to or greater than 1.0 are considered as reactive. The study was approved by Institutional Ethical Committee before commencing the study.

\section{Results and Discussion}

A total number of 39874 patients from both inpatient department (IPD) and outpatient department (OPD) departments were enrolled during the study period with fulfilling the inclusion and exclusion criteria. Out of 39874 patients, $30841(77.3 \%)$ were married and 9033 (22.7\%) were unmarried. The genderwise distribution of sample source shown in Figure 1. Among them 8,558 $(21.5 \%)$ were from rural areas, 21,298 (53.4\%) from urban areas and 8,376 (21\%) from sub urban areas and 1,642 (4.1\%) from tribal areas.
Out of these patients, 249 samples were HBsAg positive (0.62\%), 191 (76.7\%) were males and $58(23.3 \%)$ were females. Majority of the HBsAg positive patients belonged to age group 38- 47 years $(28.1 \%)$. Age and genderwise distribution of HBsAg positive patients shown in Table 1. The seroprevalence of HBsAg were found to be more or less equal among the OPD (50.2\%) and IPD (49.8\%).

Among the HBsAg positive, majority were found to be admitted to general medicine $(65.5 \%)$, followed by ICU (16.9\%) and general surgery ward $(8.8 \%)$.

Wardwise distribution of $\mathrm{HBsAg}$ positive patients are shown in Table 2.

Out of 39874 patients, 51 samples were anti $\mathrm{HCV} \mathrm{Ab}$ positive $(0.1 \%)$.Among them, 28 $(54.9 \%)$ were males and $23(45.1 \%)$ were females. Majority of the anti HCV Ab positive patients belonged to age group 58- 67 years (47.0\%). Age and gender wise distribution of anti $\mathrm{HCV} \mathrm{Ab}$ seropositive sample shown in Figure 2.

Majority of the anti $\mathrm{HCV} \mathrm{Ab}$ seropositive patients were from general surgery $((39.2 \%)$, followed by ICU (21.6\%) and general medicine (19.6\%). Samples from ENT and Ophthalmology department were seronegative for anti $\mathrm{HCV} \mathrm{Ab}$. Wardwise distribution of anti $\mathrm{HCV} \mathrm{Ab}$ seropositive sample given in Table 3. Among 300 seropositive samples, only one sample $(0.3 \%)$ was positive for both HBsAg and anti HCV Ab.

Hepatitis B virus and Hepatitis $\mathrm{C}$ virus infections are the most common viral infections known to humanity worldwide. An estimated 2 billion and 180 million people globally have been infected with HBV and $\mathrm{HCV}$ are at risk of developing liver cirrhosis or liver cancer (Franco et al., 2012 and Averhoff et al., 2012). 
Table.1 Age and genderwise distribution of HBsAg positive sample source

\begin{tabular}{|c|c|c|c|}
\hline \multirow{2}{*}{ Characteristics } & \multicolumn{3}{|c|}{ HBsAg Positive } \\
\cline { 2 - 4 } & $\begin{array}{c}\text { Total } \\
n=249(\%)\end{array}$ & $\begin{array}{c}\text { Male } \\
n=191\end{array}$ & $\begin{array}{c}\text { Female } \\
n=58\end{array}$ \\
\hline Age group in years 18- 27 & $48(19.3)$ & 37 & 11 \\
\hline $28-37$ & $46(18.5)$ & 33 & 13 \\
\hline $38-47$ & $70(28.1)$ & 64 & 6 \\
\hline $48-57$ & $41(16.5)$ & 27 & 14 \\
\hline $58-67$ & $44(17.6)$ & 30 & 14 \\
\hline
\end{tabular}

Table.2 Wardwise distribution of HBsAg positive patients

\begin{tabular}{|c|}
\hline Name of the ward \\
\hline General Surgery \\
\hline General Medicine \\
\hline ENT \\
\hline Ophthalmology \\
\hline Obstetrics and Gynaecology \\
\hline ICU \\
\hline Orthopaedic Surgery \\
\hline
\end{tabular}

\begin{tabular}{|c|c|}
\hline HBsAg Positive, $n=$ & HBsAg negative, \\
249(\%) & $n=39625(\%)$ \\
\hline $22(8.8)$ & $8717(22)$ \\
\hline $163(65.5)$ & $21387(54)$ \\
\hline $1(0.4)$ & $467(1.2)$ \\
\hline $2(0.8)$ & $861(2.1)$ \\
\hline $4(1.6)$ & $4359(11.0)$ \\
\hline $42(16.9)$ & $993(2.5)$ \\
\hline $15(6.0)$ & $2841(7.2)$ \\
\hline
\end{tabular}

Table.3 Wardwise distribution of anti HCV Ab seropositive sample

\begin{tabular}{|c|}
\hline Name of the ward \\
\hline General Surgery \\
\hline General Medicine \\
\hline Obstetrics and Gynaecology \\
\hline ICU \\
\hline Orthopaedic Surgery
\end{tabular}

\begin{tabular}{|c|}
\hline HCV Positive, $n=51(\%)$ \\
\hline $20(39.2)$ \\
\hline $10(19.6)$ \\
\hline $6(11.8)$ \\
\hline $11(21.6)$ \\
\hline $4(7.8)$ \\
\hline
\end{tabular}

Fig.1 Genderwise distribution of sample source

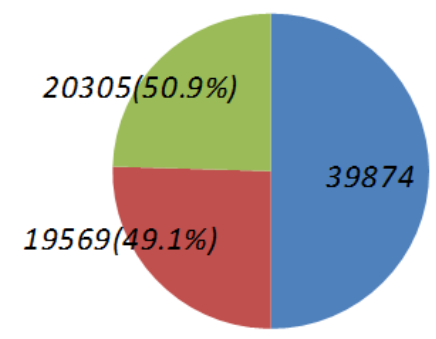

- TOTAL

- MALE

- FEMALE 
Fig.2 Age and genderwise distribution of anti HCV Ab seropositive sample

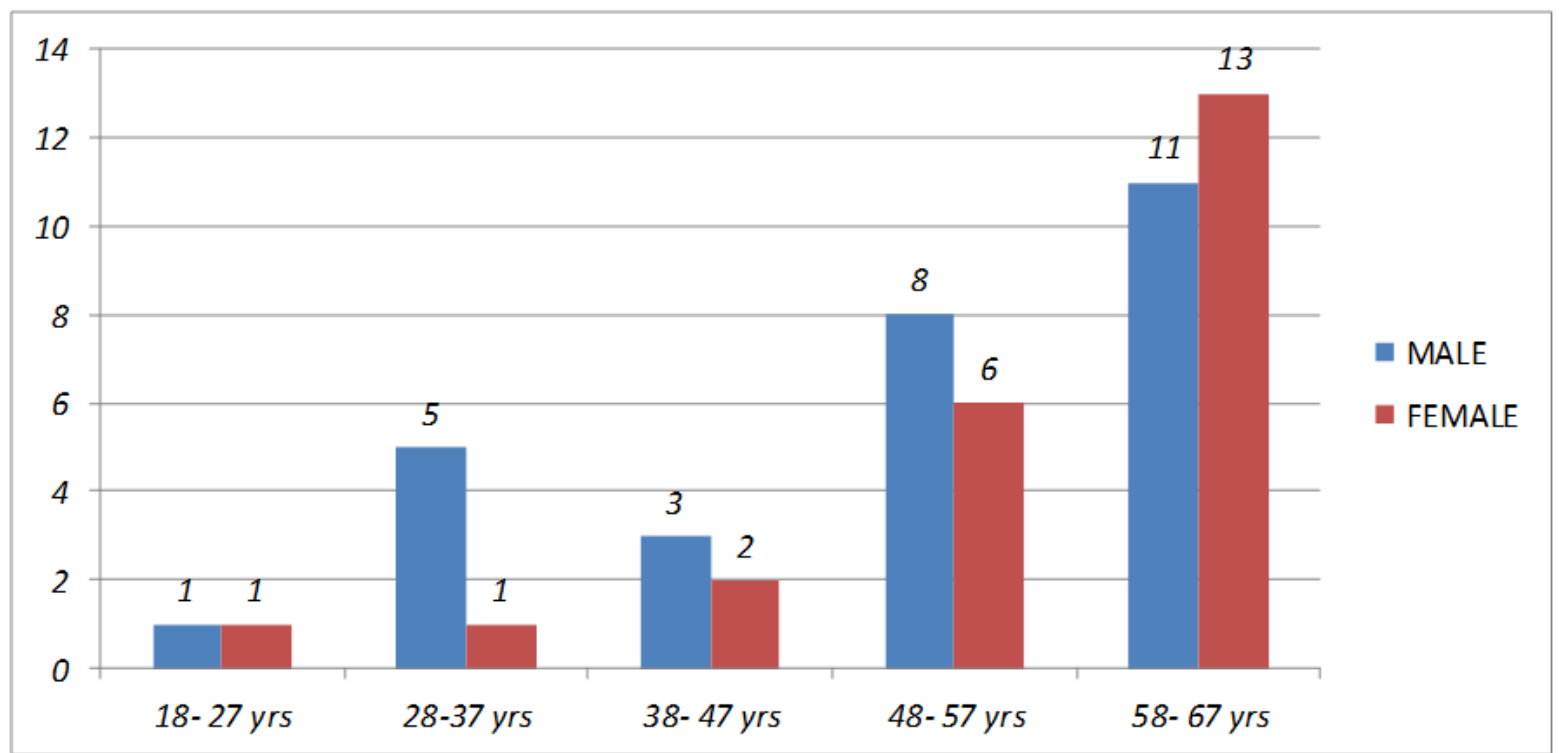

The relative importance of $\mathrm{HBV}$ and $\mathrm{HCV}$ infections varies greatly from one part of the world to another and changes over time (Te H.S et al., 2010). Prevalence of Hepatitis B varies from country to country and depends upon a complex mixture of behavioural, environmental and host factors. Our study showed $0.62 \%$ of HBsAg prevalence. Another study conducted in Karnataka is similar to our prevalence rate (Singh et al., 2009). According to Khatoon et al., 2016, the HBsAg prevalence was $3.9 \%$ and their study was higher than the prevalence rate found in our study. In our study male population showed higher prevalence $(76.7 \%)$ than females $(23.3 \%) \quad$ (Table 1). Similar observation was reported by other studies Khatoon et al., 2016, Sood et al., 2010, Quadri S et al., 2013. The reason for the higher prevalence in males in general population is not yet clearly explained (Qamer et al., 2004).

In this study, the seroprevalence of $\mathrm{HBsAg}$ was highest among age groups 38- 47 years (28.1\%), followed by $18-27$ years $(19.3 \%)$, $18.5 \%$ in $28-37$ years $(18.5 \%)$ and the prevalence decreased among age 58- 67 years (17.6\%), followed by $48-57$ years $(16.5 \%)$ (Table 1). Study conducted by Khatoon et al., in North India showed number of positive cases was highest among age groups 28- 37 years $(37.7 \%)$, followed by 38- 47 years $(29.5 \%)$ and the prevalence decreased being $13.1 \%$ among $48-57$ years and 1.6\% among 58-67 years age group In our study married population showed higher seropositive (76.7\%) when compared with unmarried population and our study in concurrence with Khatoon et al., (2016).

Our study showed that the seropositive of anti-HCV Ab was found to be $0.1 \%$. This seroprevalence is lower than the seroprevalence (4.8\%) reported by Bhattacharya et al., 2003. In our study, the seroprevalence of anti $\mathrm{HCV} \mathrm{Ab}$ was highest among the age groups 58- 67 years shown in (Figure 2) was in concordance with study of Ahmad et al., reporting the Hepatitis $\mathrm{C}$ to be highly prevalent in the age group between 55 64 years (Ahmad et al., 2004). Study of Sood et al., 2010 and Abdel-Aziz et al., 2000 is in concurrence with our study for the higher 
prevalence of anti $\mathrm{HCV} \mathrm{Ab}$ among the male gender (Figure 2). In our study, only one sample $(0.3 \%)$ was positive for both HBsAg and anti $\mathrm{HCV} \mathrm{Ab}$. This similar seropositive for both $\mathrm{HBsAg}$ and anti $\mathrm{HCV} \mathrm{Ab}$ was documented by study of Naeem et al., (2012).

The screening of Hepatitis B and Hepatitis C viral infection among the patients attending a tertiary care hospital enlightens the details of seropositive being unnoticed. People must be educated about HBV and HCV infections and their mode of transmission to prevent the spreading of disease. This study provided much important information concerning the prevalence of Hepatitis B and C and these data will serve as an important source of data for the evaluation as well as for future preventive measures.

\section{References}

Abdel- Aziz, F., Habib, M., Mohamed, M. K., Abdel- Hamid, M., Gamil, F., Madkour, S. and Anwar, W. 2000. Hepatitis $\mathrm{C}$ virus (HCV) infection in a community in the Nile Delta: population description and $\mathrm{HCV}$ prevalence. Hepatology, 32(1), 111115.

Ahmad, I., Khan, S. B., urRehman, H., Khan, M. H., and Anwar, S. 2004. Frequency of Hepatitis B and Hepatitis C among cataract patients. Gomal Journal of medical sciences, 4(2).

Averhoff, F. M., Glass, N., and Holtzman, D. 2012. Global burden of hepatitis C: considerations for healthcare providers in the United States. Clinical Infectious Diseases, 55(suppl_1), S10-S15

Baheti, R., Gehlot, R. S., and Baheti, R. 2000.Seroprevalence of Anti HCV Ab in healthy voluntary blood donors and in high risk individuals. $\mathbf{J}$ Indian AcadClin Med, 1(3), 230-2.
Bhattacharya, S., Badrinath, S., Hamide, A., \&Sujatha, S. 2003. Seroprevalence of hepatitis $\mathrm{C}$ virus in a hospital based general population in South India. Indian journal of medical microbiology, 21(1), 43.

Chakravarti, A., Ashraf, A., and Malik, S. 2013. A study of changing trends of prevalence and genotypic distribution of hepatitis $\mathrm{C}$ virus among high risk groups in North India. Indian journal of medical microbiology, 31(4), 354.

Datta, S., 2008.An overview of molecular epidemiology of hepatitis B virus (HBV) in India. Virology Journal, 5(1), 156.

Franco, E., Bagnato, B., Marino, M. G., Meleleo, C., Serino, L., and Zaratti, L. 2012. Hepatitis B: Epidemiology and prevention in developing countries. World journal of hepatology, 4(3), 74.

Gupta, N., Kumar, V., and Kaur, A. 2004. Seroprevalence of HIV, HBV, $\mathrm{HCV}$ and syphilis in voluntary blood donors. Indian journal of medical sciences, 58(6), 255-258.

Horvat.2011 "Hepatitis B and D viruses."Manual of Clinical Microbiology, 10th Edition. American Society of Microbiology, pp 1659-1676.

Kanodia, V., Yadav, M., Bittu, R., Maheshwari, R. K., and Singh, S. K. 2015. Seroprevalence of Hepatitis B surface antigen in hospital based population of Jaipur, Rajasthan. Med Pulse-International Medical Journal, 2(3), 123-5.

Khatoon, R., and Jahan, N. 2016. Evaluation of seroprevalence of Hepatitis $\mathrm{B}$ virus infection among patients attending a hospital of semi-urban North India using rapid immunoassay test. Nigerian Postgraduate Medical Journal, 23(4), 209.

Koshy, J. M., Manoharan, A., John, M., Kaur, R., and Kaur, P. 2014. Epidemiological 
profile of seropositive blood donors at a tertiary care hospital in North India. CHRISMED Journal of Health and Research, 1(2), 91

Moosavy, S. H., Davoodian, P., Nazarnezhad, M. A., Nejatizaheh, A., Eftekhar, E., and Mahboobi, H. 2017. Epidemiology, transmission, diagnosis, and outcome of Hepatitis $\mathrm{C}$ virus infection.Electronic physician, 9(10), 5646.

Naeem, S. S., Siddiqui, E. U., Kazi, A. N., Khan, S., Abdullah, F. E., and Adhi, I. 2012. Prevalence of Hepatitis 'B'and Hepatitis ' $\mathrm{C}$ ' among preoperative cataract patients in Karachi. BMC research notes, 5(1), 492.

Panda, M., and Kar, K. 2008.HIV, hepatitis B and $\mathrm{C}$ infection status of the blood donors in a blood bank of a tertiary health care centre of Orissa. Indian Journal of Public Health, 52(1), 43.

Qamer, S., Shahab, T., Alam, S., Malik, A., and Afzal, K. 2004.Age-specific prevalence of hepatitis B surface antigen in pediatric population of Aligarh, North India. The Indian Journal of Pediatrics, 71(11), 965-967.

Quadri, S. A., Dadapeer, H. J., Arifulla, K. M., and Khan, N. 2013. Prevalence of Hepatitis B Surface Antigen in hospital based population in Bijapur, Karnataka. Al Ameen J Med Sci, 6(2), 180-2.

Singh, K., Bhat, S., and Shastry, S. 2009. Trend in seroprevalence of Hepatitis B virus infection among blood donors of coastal Karnataka, India. The Journal of Infection in Developing Countries, 3(05), 376-379.
Sood, S., and Malvankar, S. 2010.Seroprevalence of Hepatitis B surface antigen, antibodies to the Hepatitis C virus, and human immunodeficiency virus in a hospitalbased population in Jaipur, Rajasthan. Indian journal of community medicine: official publication of Indian Association of Preventive and Social Medicine, 35(1), 165.

Te, H.S., and Jensen, D.M. 2010. Epidemiology of hepatitis $\mathrm{B}$ and $\mathrm{C}$ viruses: a global overview. Clinics in liver disease, 14(1), 1-21.

Teresa, L., 2006. Introduction to chronic hepatitis B infection. Am J Gastroenterol 101: S1-S6

Wang, S., Chen, Y., Xu, X., Hu, W., Shen, H., and Chen, J. 2017. Prevalence of hepatitis $B$ virus and hepatitis $C$ virus infection in patients with systemic lupus erythematosus: a systematic review and meta-analysis. Oncotarget, 8(60), 102437.

World Health Organization. Hepatitis B factsheet - http://www.who.int/media centre/factsheets/fs204/en/. Accessed July 2017.

World Health Organization. Hepatitis B factsheet $\mathrm{N}^{\circ} 204$ - http://www.who.int/ mediacentre/factsheets/fs204/en/ (last accessed August 2015).

World Health Organization. Viral hepatitis http://apps.who.int/gb/ebwha/pdf_files/ EB126/B126-15-en.pdf (last accessed April 2012).

\section{How to cite this article:}

Prabina, P., S. Jayanthi, A.S. Shameem Banu and Sakunthala, S.R. 2018. Immunoassay Test for Evaluation of Seroprevalence of HBV and HCV Infection among Patients Attending a Tertiary Care Hospital. Int.J.Curr.Microbiol.App.Sci. 7(03): 169-175. doi: https://doi.org/10.20546/ijcmas.2018.703.020 